\title{
What Affects Shopper's Choices of Carrying Devices in Grocery Retailing and What Difference Does it Make? A Literature Review and Conceptual Model
}

\author{
Nils Magne Larsen ${ }^{\mathrm{a}^{*}}$, and Valdimar Sigurdsson ${ }^{\mathrm{b}}$ \\ ${ }^{a}$ School of Business and Economics, UiT Arctic University of Norway \\ Email: nils.magne.larsen@uit.no,ORCID: https://orcid.org/0000-0001-7671-0250 \\ ${ }^{b}$ School of Business, Reykjavik University, Menntavegur 1, Nauthólsvík, Reykjavik 101, Iceland \\ * Corresponding author
}

\begin{abstract}
Shopping carts, dating back at least to 1936, are not only used as an aid for shoppers to increase sales but are now being further developed and tested in relations to healthy food selection. To improve retailers' ability to discover, generate, and capture the value related to both current practice and future innovations; such as consumers using smart carts when shopping, we systematically go through the empirical literature on carrying equipment in in-store shopping. We expose how limited the literature is by revealing the scarce number of studies on the effectiveness of baskets and carts on consumer behavior and especially when classified into different research themes. The contribution is a systematic literature review and a conceptual framework covering the most important factors affecting the choice of in-store carrying equipment, as well as the consequences of these choices in terms of in-store behaviors and transactional outcomes.
\end{abstract}

Keywords: Shopping carts, shopping baskets, shopping device, smart carts, carrying equipment Word count: 8,523 (Excluding abstract, keywords, figures, tables and references.) 


\section{Introduction}

Since it was first introduced in 1936, the physical shopping cart has established itself as the dominating in-store carrying equipment for stock-up customers. Already at its introduction, the manufacturers of the carts promoted the carts’ quantitative advantages and gave a promise of increased sales volume per customer from using the retailer's “greatest salesman” (Cochoy 2009; Grandclément 2009). As such, a shopping cart can be looked at as a behavioral modificationtool that is supposed to increase sales as a consequence of diminished customer effort and normalization of larger shopping trips. Carts and shopping baskets are universal; customers are exposed to them regularly in all kinds of different types of store outlets, from department stores to convenience stores. Carts come in many different sizes and forms; including deeper carts, swallow carts, and two, or more, baskets carts, with two floors, some have chain-locks, and others have even been turned into a crocodile or a motor car, for children. Yet, still, a universal model explaining and measuring their effectiveness is lacking. Furthermore, their potential to generate value is currently being explored in terms of transferring sales devices traditionally connected to e-commerce over to physical retailing space (e.g., personal recommendation on smart cart's screen), but with a surprisingly limited knowledge of consumer behavior behind it. Despite their long history, practical importance and potential, the literature on carrying equipment is rather scarce and spread. Little is, for instance, publicly known about customers' choices and preferences for different carrying equipment and their implications. For example, there is no empirical data on influencing factors on the decision between different types of carrying equipment; in terms of selecting between no equipment (nothing), baskets, carts - or between different types of carts. 
Our review of the literature demonstrates that there is an interest in studying further innovations in the retail space to increase sales. Not only in general, but also for products of social significance, or more in line with a sustainable "triple bottom line" of profit, people and planet (Elkington 2013). According to Wansink (2017), who talks about "healthy retailing”; modified versions of carts (e.g., bifurcated or smart carts) are a part of a research-led evolution on how healthy food will be sold in grocery stores in the future. This is, for example, evident from a recent uprising of studies focusing on shopping carts' usefulness to influence sales of healthy food (Payne et al. 2014; Wansink et al. 2017; Wansink et al. 2013; Wansink 2017). All these research streams need to build on findings on the effects of carrying equipment on consumer behavior. For instance, most managers believe in the power of shopping baskets and carts to increase sales, but little is publicly known about the proportion of customers using carts, as well as the antecedents and consequences of this choice. Given the importance of shopping carts, as well as increased research on technological innovation such as automation and robotics (e.g., Burns 2016; Sales, Martí, Marín, Cervera, and Sanz 2016; Kahl, Spassova, Schöning, Gehring, Krüger 2011; Underhill 2009), we feel that it is necessary to review the literature and to develop a conceptual framework for studies focusing on carrying equipment in shopping situations.

In the next section, we therefore introduce a conceptual framework that includes relevant variables deduced from our systematic review of the literature concerning consumer-related instore product carrying equipment in physical retail settings. Following this, we report the method and results of our literature review before we discuss in more detail each variable in the proposed conceptual framework separately. As a part of our discussion, we propose a list of interventions consisting of in-store tactics retailers can use to increase the likelihood of their customers 
choosing a shopping cart (a regular cart, smart cart, "healthy cart” etc.). Our main contribution is to introduce to the literature a largely unexplored research area that should warrant more attention by marketing researchers and practitioners, and a direction for this attention (conceptual model and a research agenda).

\section{Conceptual Framework}

The purpose of presenting a conceptual model (Figure 1) is to integrate relevant research on carrying equipment in stores as well as to identify important gaps in the literature. A conceptual model should assist in developing knowledge in terms of probabilities that a consumer will choose carrying equipment when shopping, both in terms of type and design of the equipment, including not choosing one. Then the model should explain and predict important in-store behaviors and transactional outcomes. Thus, the conceptual model builds on previous findings in the literature on carrying equipment. Still, as the literature is scarce the model is also under the influence of more general consumer and in-store marketing studies (see e.g., Foxall 2017; Grewal, Roggeveen and Nordfalt, 2014; Sigurdsson, Larsen, and Fagerstrøm, 2016). It is the quest to understand consumer choice of in-store carrying equipment and the factors that influence it, especially those situational factors that are amenable directly to an experimental analysis.

There are only a few studies that have examined behavioral differences based on consumers carrying equipment selection, or lack thereof (see e.g. Larsen, Sigurdsson and Breivik 2017; Seiler and Pinna, 2017; Van den Bergh, Schmitt, and Warlop 2011). The shortage of studies focusing on the absence of carrying equipment is rather surprising, especially when the general trend worldwide shows that many consumers visit grocery stores more frequently, and 
have a greater preference for smaller store formats (Nielsen 2015), therefore preferring the use of carrying equipment to a lesser degree. We here introduce a conceptual model, including influencing factors, the choice of carrying equipment, and the behaviors and outcomes linked to different carrying equipment choices. This can be in terms of customer experiences, in-store behaviors and transactional outcomes. The conceptual model presents a systematic analysis focusing on the choice of in-store carrying equipment as an important decision-making at the start of the customer journey. The choice of in-store carrying equipment has the possibility to affect the whole customer journey, which underpins its relevance and importance. It has its influencing factors, both in terms of the physical retail environment, as well as in terms of some more moderating factors describing the consumer walking into the store. In line with the Behavioral Perspective Model of consumer choice (Foxall 2017), the conceptual model describes consumer choice behavior as mostly the function of its consequences. Consumer selection of carrying equipment is determined by both retail and consumer factors (the consumer-behavior setting). In line with the summative Behavioral Perspective Model (BPM) of consumer choice (Foxall 2017), the conceptual model in Figure 1 describes consumer choice behavior as the function of its consequences (see Sigurdsson, Larsen \& Fagerstrøm, 2016, for behavior analysis of in-store behavior). According to Foxall (1998); “[t]o explain consumer behavior is to locate itin space and time, at the intersection of a learning history and a current behavior setting” (p. 322). This is represented in Figure 1. Consumer selection of carrying equipment is influenced by consumer factors (where we have identified in-direct measurements of learning history, as it tends not to be amenable to an experimental analysis) and the situational retail factors (actionable factors in the current retail setting). Together they form the consumer situation, the temporal and spatial contexts for the selection of carrying equipment (for more information on the BPM and 
experimental analysis of consumer choice see Fagerstrøm \& Sigurdsson, 2016; Foxall, 2015).

The probability of carrying equipment selection is understood as a Skinnerian (Skinner, 1984)

process with choice behavior variation happening both between consumers as well as with-in the activities of the same consumer, and with recurring instances with consequences that shape and select behavior among the competing availability of different carrying equipment. An experimental analysis involves testing the effects of getting (effort), using (different options) and rewarding (incentives) on shopping experience, behavior and transactional outcomes. The retail factors can consist of numerous of discriminative stimuli and motivating operations that encourage or hinder the consumer choice. These factors, such as the location of the carrying equipment, the size of the equipment and other tangible attributes can be manipulated to a greater extent and be subjected to experimental analysis. Others are consumer attributes and are therefore not directly manipulative in terms of experimental language. From our review of the literature on carrying equipment, we identify several such variables.

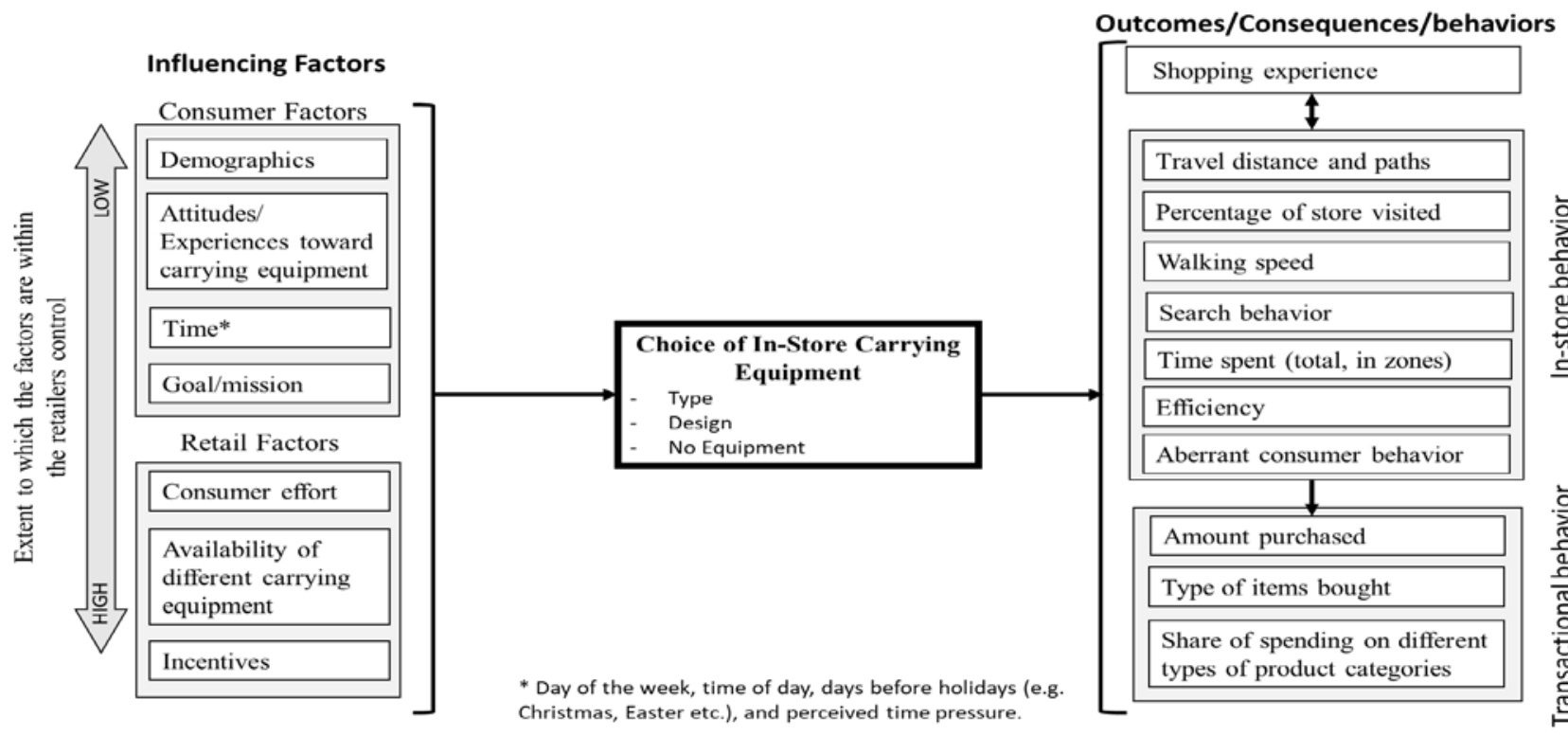

Figure 1: Research on the choice of in-store carrying equipment in retailing: a conceptual framework 
More details regarding the factors within the model are to be found in the section following our literature review.

\subsection{Scope of the literature review and review results}

The aim of the review was to identify all relevant articles dealing with any type of consumerrelated in-store product carrying equipment in physical retail settings. We defined carrying equipment as any tool helping consumers carrying their shopping in the physical store. To be retained, an article should be a full research paper (not an extended abstract), empirical and published in a peer-reviewed journal. The articles of key interest were those having one or more of the physical carrying equipment as primary object of the study.

We recognize that there are many types of alternative carrying equipment available to consumers for carrying their purchased items in the store. These are not limited to those offered by the retailer (e.g. different types of carts and baskets). Consumers can also bring with them their own devices to carry their purchases, including small shopping trolleys that are customerowned and kept at home (caddy), reusable bags, backpacks, and baby strollers (see e.g. Hanson 2015; Hageberg and Normark 2015; Kwong, Lail, Spicciolato and Wong 2010). However, in this literature review we focused on in-store carrying equipment, owned and offered to consumers by the retailer.

In-store carrying equipment goes under different names in the literature, such as “shopping support” (Van den Bergh, Heuvinck, Schellekens, and Vermeir 2016; Van den Bergh, Schmitt, and Warlop 2011), or “shopping aid” (Underhill 2009). A first step was to conduct a literature search (full text) based on these keywords as well as "shopping cart”, "shopping 
trolley”, “shopping basket”, "hand-held basket”, “divided shopping carts”, "half-carts”, “carrying equipment” and "shopping device”. Databases used were EBSCO (Business Source Premier), ABI/Inform (ProQuest), Web of Science and Google Scholar. Furthermore, we conducted a reference analysis of the latest published articles satisfying the study selection criteria (e.g. Martin et al. 2014; Van den Bergh, Schmitt, and Warlop 2011; Wansink, Soman and Herbst 2017), followed by a citation analysis of articles discussing the invention of the shopping cart (Cochoy 2009; Grandclément 2009), and the role of carts in shaping exchanges in supermarkets (Cochoy 2008). One researcher independently screened titles and abstracts of retrieved articles for eligibility. That search process resulted in the identification of 77 articles published in the period 1979-2017. The same researcher then downloaded the eligible articles and shared these with a second researcher as a basis for a full-text review to determine inclusion/exclusion. Both researchers conducted a full-text review of the 77 eligible articles. The full-text review resulted in 53 articles meeting the criteria for inclusion (69 percent of all eligible articles).

A second step was to expand our search criteria to include the role of shopping carts/baskets in consumer perceptions of convenience (or a lack thereof). We therefore added the keywords “convenience” and "customer convenience”, to the search terms "shopping cart”, “shopping basket”, “shopping trolley, and "shopping device”. Ten new articles satisfying the criteria for inclusion were identified. The final list of relevant articles therefore consisted of 63 relevant articles. We organized the 63 relevant articles in seven categories reflecting issues, or research streams, of relevance to consumer-related in-store product carrying equipment. We used content analysis as a method for constructing categories of issues/themes and to classify the relevant articles in terms of the categories (Krippendorff 1989). The procedure we used was first to work through each relevant study with the aim of deducing tentative categories reflecting 
issues of relevance, and then to classify each article in terms of the categories deduced. We revised the tentative categories following a feedback loop, and then reduced them to the six categories listed in Table 1 . Table 1 also shows the number of relevant articles in each category, the category share (in percentage) of all relevant articles, and a timeline for the publication year of the articles in each category. The numbers in each cell are unique reference numbers (ID) to each relevant article. They will appear in the text following Table 1, when the appropriate article is referred to.

Table 1. Six categories reflecting issues of relevance to in-store carrying equipment

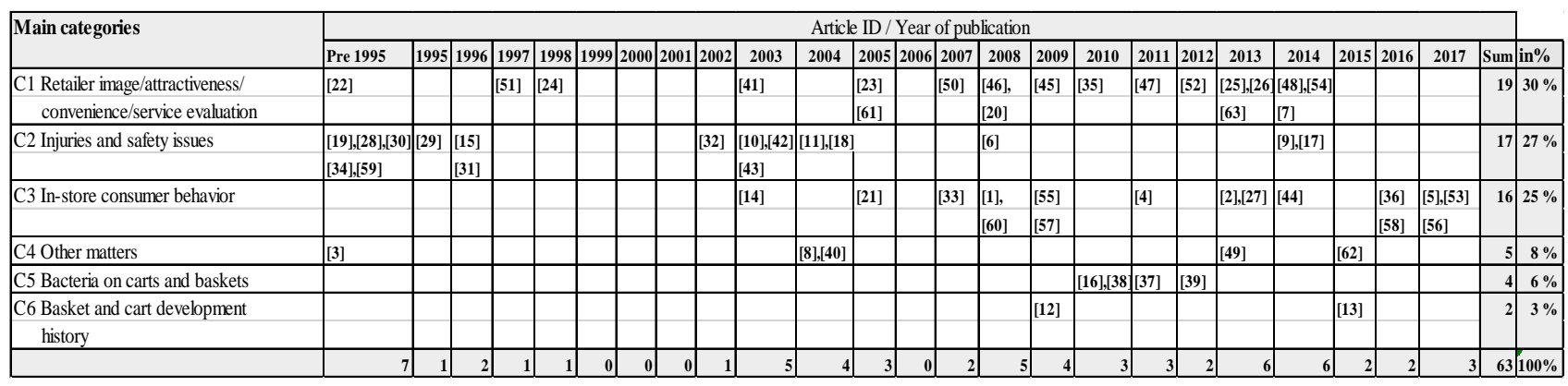

The six main categories in Table 1 are listed in descending order based on the number of occurrence of articles per category. They include retailer image, attractiveness, convenience, and service evaluation (C1), injuries and safety issues (C2), in-store consumer behavior (C3), other matters (C4), bacteria on carts and baskets (C5), and basket and cart development history (C6). Each category is discussed in more detail in what follows.

Category C1 (Retailer image, attractiveness, convenience, and service evaluation) includes 19 articles, and nine of these examine the experiences of elderly consumers in supermarkets (Angell, Megicks, Memery and Heffernan 2014 [48]; Yin, Pei and Ranchhod 2013 [25]; Kohijoki 2011 [47]; Meneely, Burns, and Strugnell 2008 [46]; Meneely, Strugnell, and Burns 2009 [45]; Pettigrew. Mizerski and Donovan 2005 [23]; Aylott and Mitchell 1999 [24]; 
Leighton and Seaman 1997 [51]; and Mason and Bearden 1979 [22]). Relevant issues identified in these articles include; difficulties of loading and unloading a shopping cart due to its depth [22, 23, 25, 51], difficulties in maneuvering carts, pushing carts, move around inside the store [23, 24, 47, 51], coin-locks on carts [24, 25], the use of shopping carts as a walking aid [25,45], collisions resulting in embarrassing situations [24], the popularity of smaller shallow carts [45, 46], difficulties of carrying baskets [51], the design and maintenance of carrying equipment [23, $25,45,46,48]$, returning the shopping cart [25], and availability of carts and baskets [23, 46]. The remaining ten articles in category C1 examines; views on shopping trolleys that are customer-owned and kept at home (Kwong, Lail, Spicciolato and Wong 2010 [35]), store patronage behavior and loyalty (Pandey and Darla 2012 [52]; Moutinho and Hutcheson 2007 [50]), attributes defining store convenience (Reimers 2013 [26]), store variables affecting customer satisfaction (Siebers, Zhang and Li 2013 [63]; Geuens, Brengman and S’Jegers 2003 [41]), consumers' perceived risks in grocery shopping (Mitchell and Harris, 2005 [61]), the experiences of children participating in food shopping (Marshall 2014 [54]), and consumers attitudes to new types of shopping carts, so called smart carts (Evanschitzky, Iyer, Pillai, Kenning and Schütte 2015 [7]; Dominici, Matić, Abbate and Fatta 2016 [20]).

As Table 1 demonstrates, category C2 (Injuries and safety issues) is also among the most researched issues related to in-store carrying equipment (27 percent of all relevant articles). It encompasses three research streams. The first stream of research includes articles on injuries caused by children falling out of carts (Martin et al. 2014 [17]; Wright et al. 2008 [6]; Vilke et al. 2004 [18]; Parry et al. 2002 [32]; Smith et al. 1996 [15]; Smith et al.1995 [29]; and Campell et al. 1990 [34]). The second reports findings from behavioral interventions such as verbal prompts and warning signs to increase frequency of safety belt usage and/or to prevent accidents (Clayton 
et al. 2014 [9]; Barker et al. 2004 [11]; Harrell 2003a [10]; Harrell 1994 [28]; Ferrari \& Baldwin 1989a [19]; and Ferrari \& Baldwin 1989b [59]). The third stream is more diverse. It includes observations of children in shopping carts (Harrell 2003c [43]; Harrell and Reid 1990 [30]), experiments with different types of shopping carts to detect the likelihood of injuries (Harrell 1996 [31]), and observations of safety habits of adults accompanying small children in supermarkets (Harrell 2003b [42]).

Category C3 (In-store consumer behavior) contains 16 articles involving one or more types of carrying equipment, and that provides data on user characteristics and/or consumers' instore behaviors (such as paths, buying behavior, area coverage, and time in store). Only five of these articles involve more than one type of carrying equipment (Seiler and Pinna 2017 [56]; Larsen, Sigurdsson and Breivik 2017 [53]; Wansink, Soman and Herbst 2017 [5]; Wansink, Payne, Herbst and Soman 2013 [27]; and Van den Bergh, Schmitt and Warlop 2011 [4]). This literature is as such rather scarce. The in-store behaviors they examine relate to the right side of Figure 1, and include search behavior [56], number of purchases [53, 56], walking speed [56], and types of purchases [4, 5, and 27]. Beside Larsen et al. [53], none of these articles analyze the consumers' choice between alternative carrying equipment, including the behaviors of nonequipment users ("the choice of in-store carrying equipment” in the conceptual model presented in Figure 1). Van den Bergh et al. [4] focus on behavioral differences between shoppers using a shopping cart and those using a basket. Their sample of basket users is very small compared to their sample of cart users. Similarly, Wansink et al. [5, 27] study the effects on purchase behavior of consumers using a divided shopping cart instead of a regular shopping cart, and not the choice itself. Further, Seiler and Pinna [56] examine the effect on search time from consumers' using a basket instead of a shopping cart (time spent in front of the shelf when 
picking up a product to purchase). They emphasize the fact that not all of the shopping carts and baskets in the store were equipped with RFID tags, and that they only observed path data for a subset of all store visits. Only two of these studies use an experimental design [5, 27], while the other three are non-experimental correlational field studies.

The majority of articles in category C3 provide insight only into the behaviors of customers using a shopping cart (Sales, Martí, Marín, Cervera and Sanz 2016 [58]; Wang and Chang 2016 [36]; Wagner, Ebster, Eske and Weitzl 2014 [44]; Van Ittersum, Wansink, Pennings and Sheehan 2013 [2]; Hui, Fader and Bradlow 2009a [55]; Hui, Bradlow and Fader 2009b [57]; Cochoy 2008 [1]; Kulyukin, Gharpure and Coster 2008 [60]; Hosbond and Skov 2007 [33]; Larson, Bradlow and Hui 2005 [21]; and Kourouthanassis 2003 [14]).

Only six of the articles in category C3 examine in-store behaviors other than transactional behavior (Figure 1, right side). Larson et al. [21] study movement patterns in combination with shopping duration to identify dominant in-store shopping paths. Hui et al. [55] examine consumers deviations from their most optimal in-store path based on their actual purchases. Wagner et al. [44] combine in-store movements and shopping duration with data on where customers stop and park their shopping carts while continuing shopping. However, their primary interest is the relationship between cart parking behavior and purchase behavior. Cochoy [1] on the other hand, examine data on a wide array of in-store behaviors centered on shopping cart usage. It includes behaviors such as how consumers put bulky items in the shopping cart, how things are arranged in the shopping carts, the quantity of items in the shopping carts (filling-up rate), who pushes the cart, who sits in, as well as demography (how many people, which age, and gender). Sales et al. [58] examine how a person-following shopping cart assistance robot 
function in the retail store when assisting older shoppers, and Wang and Chang [36] demonstrate how the use of a smart cart with sensors saves consumers for walking time inside stores.

We recognize that only six of the articles in category C3 [2, 14, 33, 36, 58, and 60] examine consumers' using or testing a robotic shopping cart or a "smart" shopping cart (such as carts with tablets or screens for communication, product location and scanning purposes). Sales et al. [58] and Wang and Chang [36], were mentioned in the previous paragraph. Van Ittersum et al. [2] demonstrate how real-time spending feedback from an iPad with a shopping tracker attached to the shopping cart, influence purchase behavior. Both Kourouthanassis [14] and Hosbond and Skov [33] evaluate the effects of smart shopping technology mounted on shopping carts on participants shopping experiences. Finally, Kulyukin et al. [60] demonstrate that a specific robotic shopping cart enables visually impaired shoppers to reliably and independently navigate to products and to retrieve them. We find the articles on technology-based shopping carts in the area of consumer behavior and marketing to be surprisingly limited. However, it is rather likely that this literature will increase.

Category C4 (Other matters) is a "miscellaneous" category. Thus, it contains all other identified articles reporting data on behaviors related to carts or baskets not falling into the other five categories. Trinkaus (2004a [8]; 2004b [40]) provides data on how consumers behave when confronted with a shopping cart containing litter, and where consumers leave their shopping cart after use in a supermarket, respectively. Schumann et al. (1991 [3]) report data on the effectiveness of placing traditional advertisements on carrying equipment. De Groot et al. (2013 [49]) examine the influence of norms on the use of free plastic bags, and report as part of their results data on how many of their respondents that are using large carts versus smaller carts and baskets. Finally, Hanson (2015 [62]) describes cases where mothers with small children use the 
baby-stroller as in-store carrying equipment, and solutions for potential "over shopping” and “over carrying” when shopping with a baby-stroller.

Category C5 (Bacteria on carts and baskets) contains articles reporting data on the prevalence of bacteria on shopping carts and hand-held shopping baskets (Al-Gahmdi et al. 2011 [37]; Gerba and Maxwell 2012 [39]; Mizumachi et al. 2010 [38]; and Patrick et al. 2010 [16]). Similar to articles on injuries and safety issues (Category C2), these are rather clinical in nature. Nevertheless, such issues are all related to significant consequences and may affect how some consumers choose between a cart, a basket or no equipment, and are thus relevant influencing factors in the conceptual model presented in Figure 1. For instance, fear of bacteria may prevent some consumers from using any cart or baskets (attitudes toward carrying equipment).

Finally, category C6 (Basket and cart development history) entails two articles providing insight into historical aspects related to the invention of the shopping cart, and other in-store carrying equipment. While Cochoy (2009) [12] offers insight into the introduction of shopping carts in American grocery stores, Hagberg and Normark (2015) [13] discuss how "new" technologies, such as in-store baskets and shopping carts, assisted customer mobility within selfservice stores in Sweden during the early 1950s.

We find the articles in category C1 (retailer image, attractiveness, convenience, and service evaluation) and category C3 (in-store consumer behavior) in Table 1 to be most relevant in terms of adding insight to consumers' choice of in-store carrying equipment, influencing factors and outcomes/consequences/behaviors. These two categories include 35 of the 63 articles satisfying our criteria for inclusion (56\% of all relevant articles). Table 2 contains data extracted from each of these 35 articles: country of origin, research objective, study design, main variables, and main findings of relevance for in-store carrying equipment. We formulate the factors in our 
conceptual model (Figure 1) to a large extent on these articles. To make the link between each of the articles in Table 2 and the conceptual model even more explicit, we have added text in brackets in the second column (research aim) that refer to the factor(s) in the conceptual model to which the each of the 35 article add relevant insights (influencing factors, the choice of carrying equipment, shopping experiences, in-store behavior, and transactional behavior). 


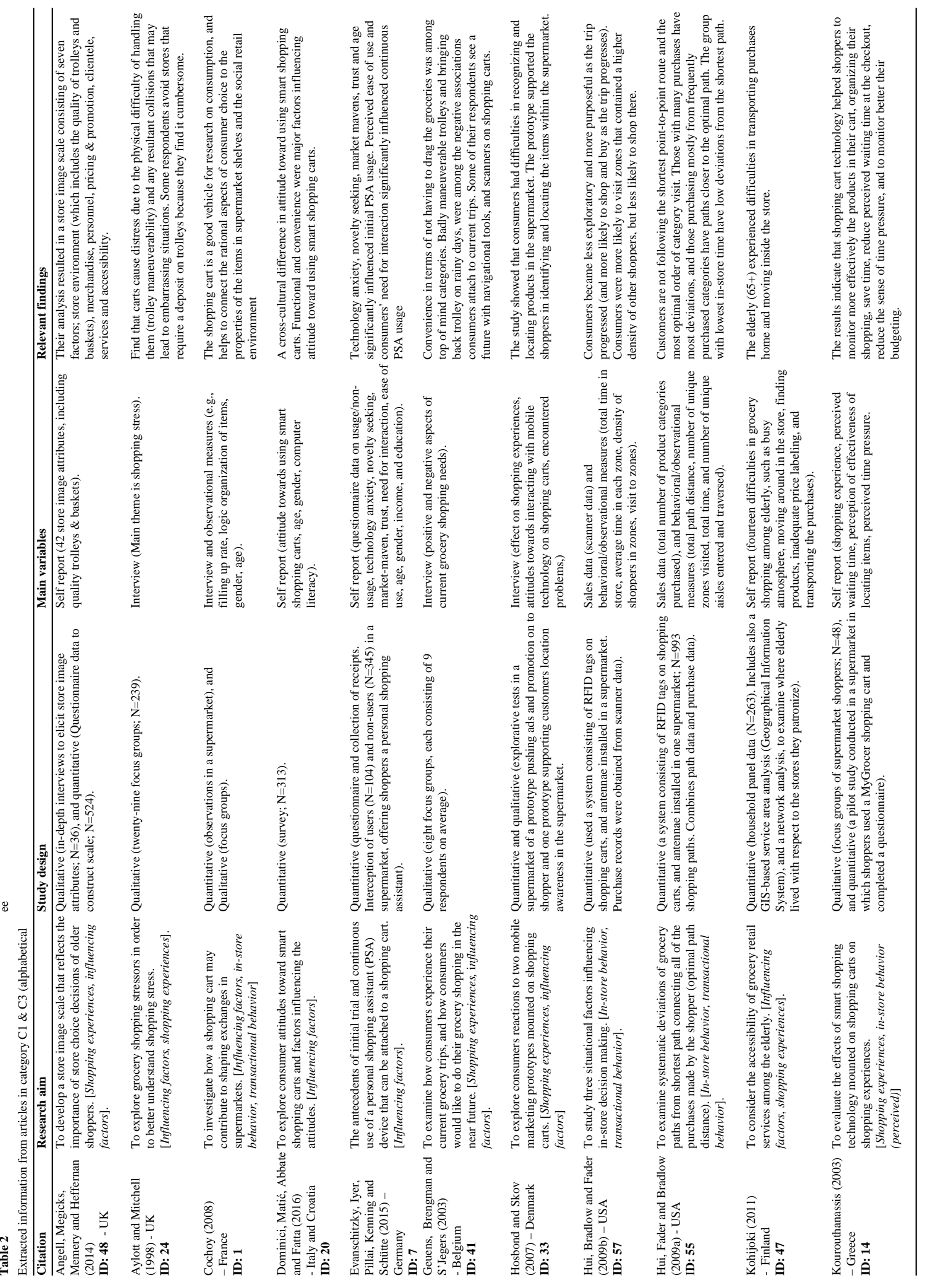




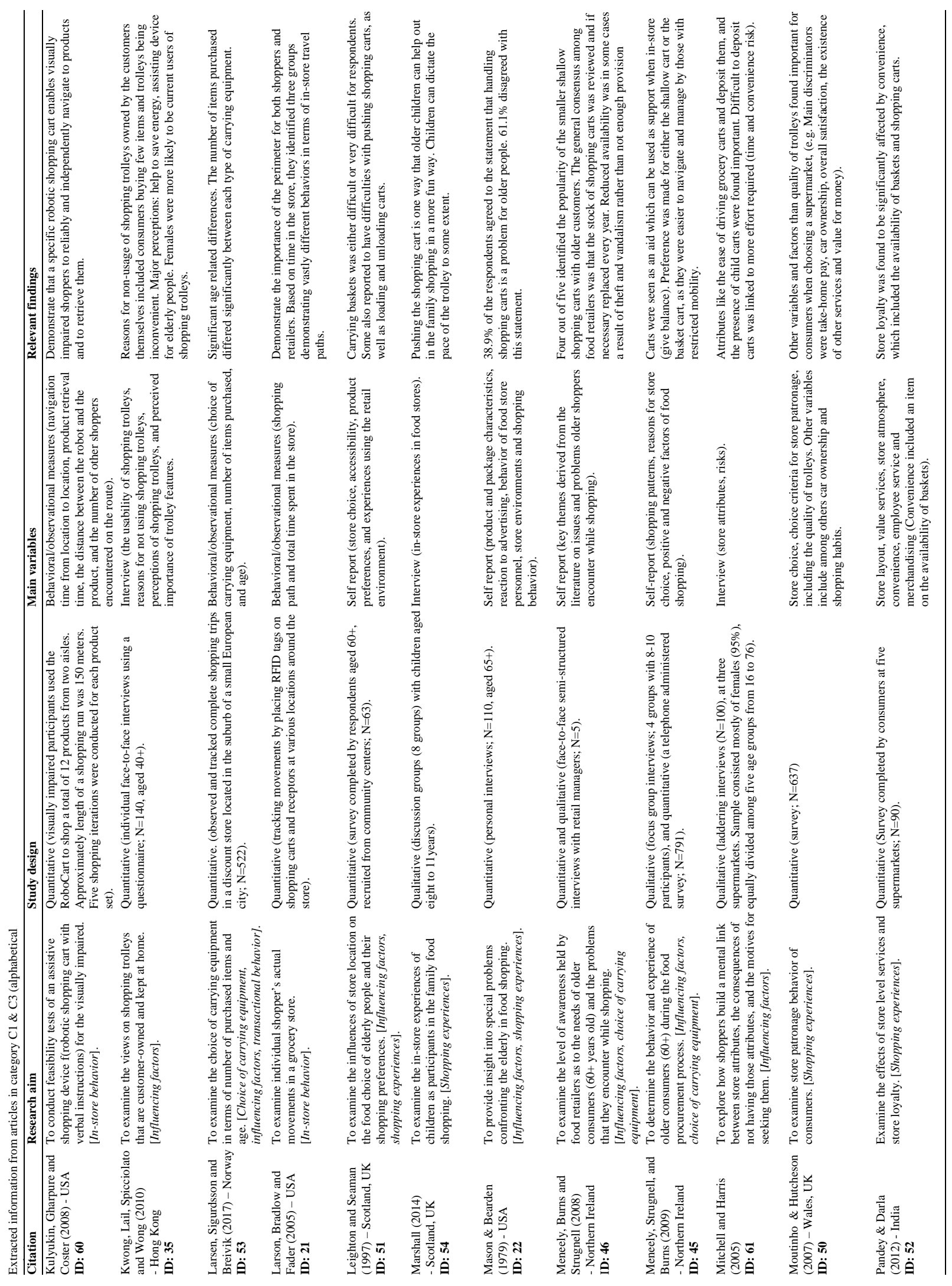




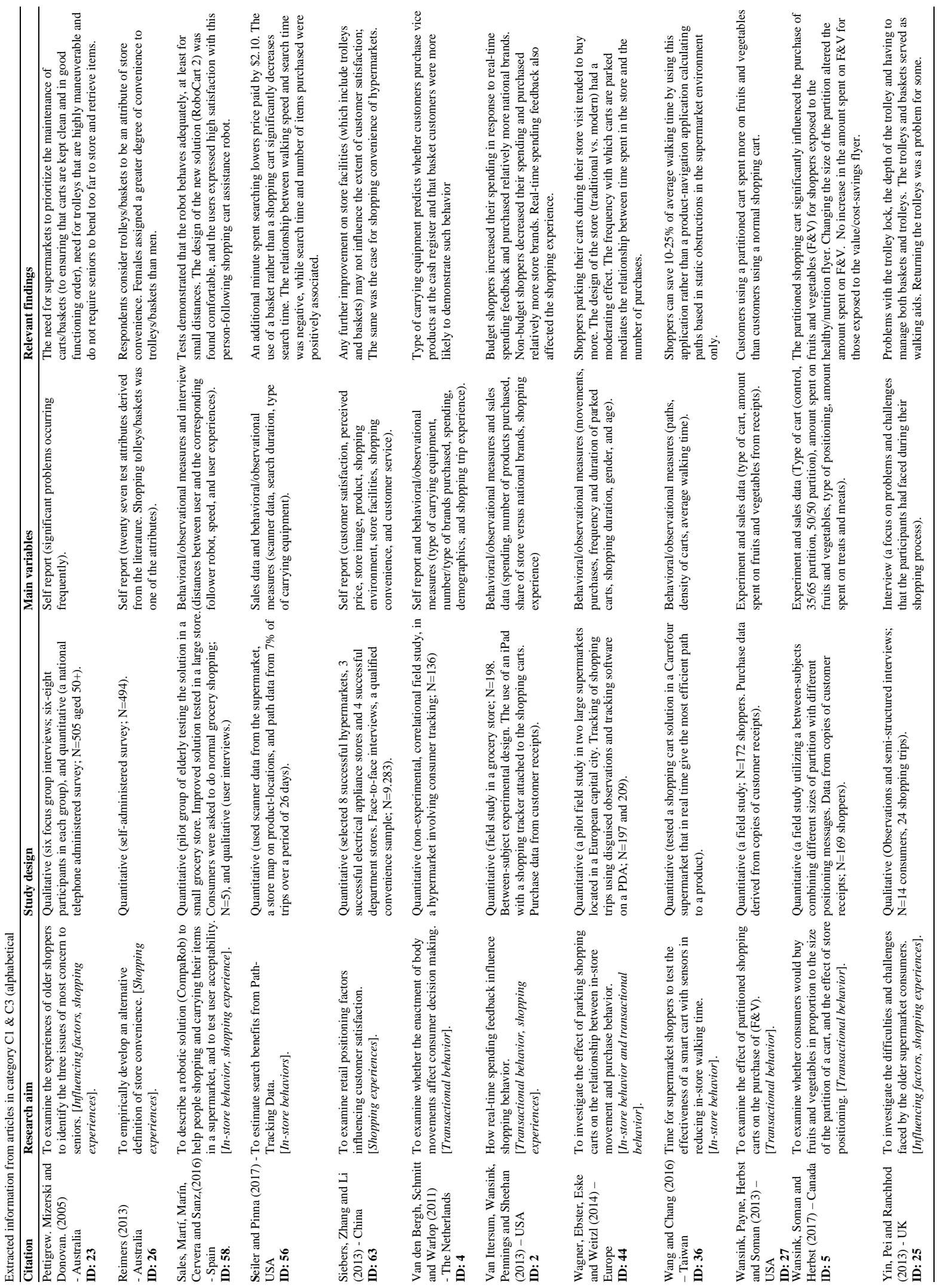




\subsection{Variables Presented in the Conceptual Model}

Looking at the review of the available literature, and organizing knowledge into our conceptual model, we can begin to create conclusions or expectations, and recommendations for future steps. Although our review of the literature demonstrates a need for more research on most of the variables, behaviors and relationships modelled in Figure 1, there are some gaps standing out as more important than others. In particular, we recommend that consumer's choice between alternative carrying equipment, at the very start of the shopping trip, undergoes rigorous empirical examination. This choice can affect both the shopping experience as well as the overt in-store behavior, but the extent of this effectiveness also lends itself to an important empirical examination. In line with the literature mentioned above, consumer and retail factors have reciprocal effects on each other, but together they present the environment/stimuli that can motivate and set the occasion for choice of carrying equipment, affecting the shopping experience, in-store behavior and its outcomes.

The conceptual model in Figure 1 enlists, as a consequence, these two influencing factors on the choice of carrying equipment (consumer factors and retail factors). Consumer factors, like demographics, attitudes/experiences, time, and goal/mission, are to a lesser extent within retailers control than the retail factors. These retail factors include attractiveness/incentives, consumer convenience/effort, and the availability of different carrying equipment, all factors in the retailing setting and mostly or totally controlled by the retailer. Both consumer and retail factors are shown on a continuum, demonstrating that the retail factors are more amenable to an experimental manipulation, or practical intervention. These factors then go on to affect the choice of carrying equipment, and therefore the overall shopping trip. The model in Figure 1 focuses not only on economic outcomes of the shopping trip itself but also on customer 
experiences and in-store behaviors throughout the whole shopping journey. Until recently, such behaviors during the entire in-store journey have been mostly unavailable, and have thus been a kind of "black box" for both retailers and marketing researchers. Though now with new technology (such as video surveillance and retail analytics), in-store behavioral variables that are now measurable include travel distance in meters, paths, walking speed, percentage of store visited, time in store, number of categories visited, and amount/percentage of time used to navigate versus to shop, just to mention a few (Fig.1, right side). Measuring these variables paves the way for more detailed studies on in-store behavior beyond mere transactions.

\subsubsection{Consumer Factors}

The literature has identified a relationship between a few consumer factors (or sociodemographic variables), the choice of carrying equipment, and derived in-store behaviors. These findings, described below in a short manner, include gender, age and family size. The literature is, however, limited and there is not only a need for more studies on these variables but also others, such as location - or the distance from the store, income, or even a combination of sociodemographic variables.

There are a few studies related to gender. Reimers (2013) found that women assigned a significantly greater degree of convenience to shopping carts and baskets. According to Kwong et al. (2010), females perform more traditional or conventional family roles, and thus women purchase larger quantities on average than men do. Davies and Bell (1991) also found that men bought fewer items and used less time to complete the shopping task than females.

Age is another socio-demographic factor where we could find a few relevant publications, but mostly focused on older shoppers. As our review demonstrates, when the individual 
shoppers’ age increases, their ability to move decreases (Yin, Pei, and Ranchhod 2013). As consumers get older, they eventually find it more difficult to carry baskets and to load and unload shopping carts, especially the bigger and deeper carts (Leighton and Seaman 1997). Further, shopping carts frequently serve as a walking aid for older shoppers (Larsen et al. 2017; Meneely et al. 2009; Yin et al. 2013). Carts are also suitable for carrying a handbag, purse or other personal belongings while shopping. Although consumers at the same age can experience a quite different health situation, the limited number of findings go with the reasonable expectation that a much higher proportion of older consumers tend to choose a cart when shopping for groceries compared to younger consumers. The preferences unveiled by consumers aged $60+$ in the study by Meneely et al. (2009) provide some support. Since they preferred either a shallow cart or a basket cart, it seems likely that many other seniors when confronted with a choice of a hand-held basket or a cart would choose the cart.

The third consumer factor is family size. The bigger the household, the more likely it is that the consumer selects a shopping cart. One thing is that planning becomes more difficult as identifying and remembering the needs and desires of each family member becomes more complex (Inman et al. 2009). More important, smaller households buy fewer items. This can lead to a greater chance that larger households find a cart necessary for the shopping trip. The more needs consumers have to fulfill when shopping, the more they would need a cart, given that they are not frequently visiting the store, but that would be rather time consuming. Ceteris paribus, one could expect that a greater proportion of larger households choose a cart, but this needs to be empirically verified. Of additional benefit to large households could be technological solutions that ease the generally more complex shopping situations. This could include screens mounted 
on shopping carts or a hilt for smart phones with apps that more easily match the retailers supply and each family member’s needs.

Attitudes and Experiences a consumer has towards carts or baskets can also affect their choice of carrying equipment. If a consumer has developed negative or positive associations toward a specific carrying equipment, then this would affect his/her likelihood for choosing exactly this equipment. Our review shows that there exist relevant insight on older shoppers experience with in-store carrying equipment, such as difficulties of loading and unloading a shopping cart due to its depth (Yin, Pei and Ranchhod 2013; Pettigrew et al. 2005; Mason \& Bearden 1979; and Leighton and Seaman 1997), difficulties in maneuvering carts (Kohijoki 2011; Pettigrew et al. 2005; Aylott and Mitchell 1998; and Leighton and Seaman (1997), and difficulties in carrying baskets (Leighton and Seaman 1997). Beside this insight, we know very little about experiences and attitudes toward in-store carrying equipment within the general population. Research has also demonstrated that shoppers get exposed to various forms of bacteria (such as coliform bacteria, staphylococcus aureus and E-coli) through their interaction with shopping carts and hand-baskets (e.g. Gerba and Maxwell 2012; Mizumachi et al. 2010). Fear of infections might lead some consumers to avoid using any carrying equipment or to favor one type of equipment over another. Thus, some consumers might choose not to use carts and/or baskets because they find them contaminated (some parents let their children stand in the cart with their dirty shoes, or the carts/basket are not regularly cleaned), but this needs to be empirically verified.

Time can refer to the moment the consumer enters the store (visiting time); the time of the day, day of the week, point in the month and even time of the year, but also the extent to which the consumer is pressured for time (time pressure). This variable also reflects events that have a 
particular time, such as public celebrations or personal factors that affect the consumer's budget or willingness to buy; this can mean both time to or from external factors such as pay day. Research shows that consumers have a "shopping time budget" allocated to the shopping trip that affects their in-store decision-making (Hui et al. 2013), where time availability is positively associated with total search effort (Beatty and Smith 1987). In-store research has also shown that consumers who perceive time pressure are more purposeful (Hui et al. 2009b; Park, Iyer and Smith 1989). In theory, timing is related to the influence of consumer buying goals, but relevant research questions include if and how consumers' perceived time pressure, and their shopping time budget, influence the type of carrying equipment they find most suitable for their shopping trip, and the rest of the journey. Behaviors such as reading or looking at pictures while walking, or talking in the phone affects variables such as walking speed, the share of total time spent on non-shopping behavior, and customer efficiency (e.g. number of purchases divided by total time spent in the store). But in terms of carts the possibilities might be to study if smart carts with digital screens can augment the shopper experience, or if a handle for a smartphone on carts can increase shoppers' satisfaction and cart adoption, or if it will only lead to less active shopping overall. At least, our literature review shows an increased interest in research on smart carts, or other technologically enhanced carrying equipment, which should not be surprising given the latest trends in digital technology and artificial intelligence. From this discussion, it should be apparent that there are many interesting research questions related to this factor, and more metrics could be related to time as a variable, such as the time the consumer has been penetrating a particular store (consumer lifetime), or the lifecycle (and then frequency of store visits, rate, duration, latency and time between shopping visits). 
Consumers' goals/mission is an important consumer factor for the shopping trip as it involves how consumers think about the device needed to fulfill their shopping goals. Bell, Corsten and Knox (2011) argue that shoppers in "abstract” states are more flexible and receptive to their environments, whereas those in more precise states are "closed off" to their surroundings. While the shopping cart has been the only viable alternative for consumers driving once a week to the supermarket to accomplish their weekly shopping, the alternatives confronting consumers expand with changes in visiting behavior. Shopping or buying goals/missions have been referred to also in the discussion of previous consumer factors (e.g. demographics and time), which suggests that this variable is very influential in how consumers select among available carrying equipment when entering the store. We therefore, in particular, encourage research on the relationship between consumers' shopping goals/missions and consumers' choice of carrying equipment in different retail settings.

\subsubsection{Retail Factors}

Consumer carrying equipment often represents one of the first-choice behavior a consumer has with a retailer's product or service when visiting a store. Retail factors represent objective alterations in environments where choices can be made easier or less convenient as a behavior change technique (Wansink 2017). This method of altering the environment to make people choose one option instead of another is often called nudging and can be described as factors in the choice architecture (consumer decision setting) that alter people's behavior in an expected way without excluding or banning any options or changing their economic incentives in a significant way (Thaler and Sunstein, 2008). However, according to the Conceptual Model the choice of carrying equipment is not only under the influences of current decision frames and 
nudging, but also by the more long-term consequences of the choice experienced by the consumer. The choice of a carrying equipment can have important consequences for how the consumer can act thereafter throughout the shopping trip. As such these choices are ruled by a selection by consequences (Skinner 1981). The retail factors therefore represent the stimulus change that either functions as the consequence for behavior, signals it or alters its value.

Attractiveness and Incentives. A cart, a basket, or no equipment, brings consequences that simultaneously “reinforce” and "punish” the behavior. A particular option can be reinforced by the benefits obtained from this option, such as particular incentives or positive consequences attached to it. For instance, the carrying capacity offered by each choice affects the attractiveness of each type of equipment. Making a carrying equipment more customer friendly and rewarding means either drawing attention to the benefits or increasing the value the consumer receives. Increasing the value beyond the carrying capacity itself can be done in terms of assisting the consumer to find relevant products, to fulfill his or her goals or by using rebates or reward points attached to a particular target selection. The implementation of "smart cart"-technology that gives consumers other types of benefits than the regular shopping cart, is for instance a possible way of helping customers to select a shopping cart at the beginning of their shopping journey. The benefits found in the work of Kulyukin et al. (2008) and Sales et al. (2016) provide relevant examples.

Consumer Effort relates to the way the retailer makes alternative carrying equipment available to their customers (location, barriers etc.), and the types of equipment made available. Both the number of alternatives and the way they are presented (choice architecture) may influence what consumers chooses (Johnson et al. 2012). The way retailers present their shopping carts and baskets in the retail environment affects how easy it is it is to grab (select) 
one option relative to another, which can nudge consumers to select one type of carrying equipment instead of another without the retailer removing or banning the other option (Underhill, 2009). What consumers do cannot be reduced to their preferences, habits, or rationalities. The environment plays a role and often deviates their behavior. Thus, the retail environment can have an effect on the choice of carrying equipment itself, and the choice of for instance a shopping cart can further nudge the consumer to be a shopper and to shop in large quantities (a behavior altering effect). To test the effects of such interventions there is a need for experimental studies. Also, while cart locks, for instance, are a proven answer to prevent cart theft, these systems can be a hassle for customers (See e.g. Aylott and Mitchell 1998). Another example of effort is an incident where the consumer reaches his/her maximum carrying capacity (the basket cannot handle more items, or the capacity of the customer's arms is stretched to the limit). Also relevant are incidents in which carts are used for carrying children, returning empty bottles, or as a walking aid for elderly consumers, and not as vehicles to make larger purchases more convenient. In addition, it is quite common for consumers to park their carts, and in some incidents also their baskets, in one zone while they visit different zones of the store (Wagner et al. 2014). All these incidences occur to minimize consumers' efforts.

Availability of Different Carrying Equipment will change how consumers choose what to use when shopping a store. Reimers (2014) argue that shopping carts/baskets are among the store attributes not yet utilized to empirically define store convenience in any retail context. There exists an array of different carrying equipment in retailing today. As mentioned in the introduction, it includes scaled down shopping carts for children. Some consumers even bring with them their own personal shopping trolleys or reusable grocery bags and use these to carry their items while shopping instead of store equipment (for instance in combination with self- 
scanners). Retailers also encourage self-scanning shoppers to pack their groceries while shopping by making their disposable plastic bags available at the entrance. Carts and shopping baskets of different sizes coexist in many stores today. Each alternative has its own volume limit that provides a constraint on how much the consumer can buy. By making baskets available, the store expands the shopping capacity of consumers who do not want to shop with a cart (Cochoy 2008). On the other hand, providing consumers with alternatives to the volumetric cart may encourage some consumers that otherwise would have used a cart to deselect the cart. This is a dilemma facing retailers (Cochoy 2008).

\subsubsection{In-Store Behaviors}

Travel distance, percentage of store visited and travel paths. The more of the store consumers visit and shop, the more they become exposed to product categories, in-store displays and individual products (Hui, Inman, Huang and Suher 2013). Since exposure to categories, displays and products has the power of reminding consumers about their needs, travel distance and percentage of store visited affects shoppers' unplanned purchases and thus store sales (Hui et al. 2013). Travel distance measured in meters or feet is not necessarily an exact measure for number of exposures. The travel paths might reflect incidents were the shopper walks down aisles more than once in search for a particular product, or returns to already visited areas. A complementary or alternative measure to travel distance, which is unaffected by consumers' revisits to store zones, is percentage of store area visited. It is reasonable to expect that travel distance, percentage of store visited, and travel paths deviate based on consumers' choice of carrying equipment. Those using a larger equipment are expected to visit a larger share of the total store area and to walk longer paths. Some support is found in the study by Gil, Tobari, 
Lemlij, Rose and Penn (2009). They found that shoppers making short trips used more baskets and no deep trolleys. They also found that none of these customers was on a main shopping mission.

Walking Speed. Seiler and Pinna (2017) find basket users to exhibit a higher average walking speed than cart users. The choice of carrying equipment affect how flexible consumers are to move inside the store (Larsen et al. 2017). Carts hinder movement in the store by reducing walking speed and flexibility of walking direction (Wagner et al. 2014). The flexibility is lowest for those pushing a shopping cart and highest for those with no carrying equipment. A cart, due to its size, decelerates customers, for instance when they pass corners (in fear of bumping into other shoppers due to less overview of what meets them), meet oncoming traffic of other customer with carts, or walk behind other cart users with a slower walking speed (Larsen et al. 2017). Consumers selecting a shopping cart would as such automatically slow their pace down when doing grocery shopping. Customers with no carrying equipment have, ceteris paribus, a larger flexibility and can thus walk much faster. Carts, in particular, hinder customers who wish to complete their shopping as fast as possible. For such shoppers, carts can be very inconvenient. Since the frequency of other shoppers and/or their shopping carts differ significantly from one zone to another, consumers' walking speed would also vary from zone to zone. As Wagner et al (2014) demonstrate, this effect is most pronounced in zones with high frequency of visits and many parked shopping carts. Frequency of visits and parked shopping carts may as such moderate the relationship between usage of carrying equipment and walking speed in a zone, with a higher moderating effect on carts, since they are less flexible to maneuver around parked shopping carts and other shoppers in the aisles. Other studies have further demonstrated faster walking along the main aisles of the store and near the checkout compared to the rest of the store 
(e.g. Larson et al. 2005), and that consumers become less exploratory and more purposeful as the trip progresses (Hui et al. 2009b).

Search behavior. The literature suggests that type of carrying equipment affects how much time consumers spend in the vicinity of a product that they ultimately purchase (search time). Seiler and Pinna (2017) report findings suggesting that the use of a basket rather than a shopping cart significantly decreases search time. They also report a negative and significant relationship between in-store average walking speed and search time, and a positive and significant relationship between search time and the number of items purchased.

Shopping time (Total and in zones). Although shopping time is known to have a positive influence on consumer spending, there are only a few studies reported in the literature on how choice of carrying equipment affects how much time shoppers spend in the store. The results in these few studies (Gil et al. 2009; Van den Bergh et al. 2011) suggest that basket users spend shorter time in the store than cart users. Considering the walking speed, travel distance and carrying capacity of non-equipment users, it is reasonable to expect that this group of shoppers exhibit the shortest shopping time among all shoppers.

Shopper efficiency. Combining data on travel distance or time measures (e.g. shopping time) with purchase data for every shopper (total spending and/or number of purchased items), lead to relevant shopper efficiency measures. Consider total time in store divided on number of purchases (purchasing speed), as well as number of purchases divided on travel distance (purchases per meter). The higher the purchasing speed, the more time shoppers' use on purchasing and less on in-store navigation (travelling) or searching for items in the shelves. In the same vein, the more purchases per meter, the more efficient is their travel path. Thus, the first measure gives an indication of time efficiency, while the other gives an indication of in-store 
travel efficiency. Time efficiency can also be measured on category level as suggested by Sorensen (2016). There is an increased focus by retail specialists (e.g. Sorensen 2016; TNSglobal.com 2017) on the importance of helping shoppers to navigate stores quickly and without frustration, and that stores should be more shoppable (Burke and Morgan 2017). This requires customer-orientated retailers who measure shopper efficiency and seek to adapt their store formats to major shifts in target customer behaviors.

Aberrant consumer behavior. A limited carrying capacity can result in aberrant behavior, for instance when consumers loose products onto the floor because they at the start of the shopping trip miscalculate their exact need for carrying capacity. Such incidents may occur when consumers use their arms to carry the items, or fill their baskets to the maximum capacity and carry additional items either on the top of the basket or in their arms. Further, our review points to incidents were the use of a shopping cart result in collisions due to the physical difficulty of handling them (Aylott and Mitchell 1998). Accidents happens and can cause liability (financial loss) and/or lead to embarrassment (Larsen et al. 2017).

\subsubsection{Transactional Behaviors}

Total spending and number of purchased items. The choice of carrying equipment provides a physical constraint on the volume a shopper can buy (Cochoy 2008). Thus, the choice consumers make at the entrance has consequences for how they can behave later. The shopping capacity is largest for those choosing to use a shopping cart, and most limited for those choosing to walk into the store without any carrying equipment. There is a limit on how much a person can carry in his/her arms. When reaching this limit, the consumer would most likely stop searching and stop being attentive to stimuli, and instead start to proceed to the checkout. As 
Underhill (2009) points out, when shoppers enter a store without a cart or a basket, they tend to select additional products only as long as their hands can hold them. Consumers' walking speed also has the potential of affecting spending negatively. Those who move quickly through the store and only focus on the products they planned to purchase would be less exposed to in-store stimuli (Seiler and Pinna, 2017; Inman et al. 2009). Finally, shopping time should positively influence in-store spending. See for instance Van den Bergh et al. (2011) who found that cart users relative to basket users spend more time in the store, buy more items and spend more during their store visits.

Types of Items Bought - Volume and Weight. It is reasonable to expect that consumers on some occasions base their choice of carrying equipment on what type of items they plan to buy. Heavy or voluminous items would for instance require the shopper to use either a shopping cart or a larger basket on wheels.

Share of Spending on Different Types of Product Categories. As also shown in the conceptual model, carrying equipment innovation can have implications on transactional behavior in terms of the share of different types of food purchased. For example, Wansink et al. (2013) found that customers using a partitioned cart (e.g. a half cart) spent more on fruits and vegetables than customers using a normal shopping cart. The half-cart model is a strategy used to increase the share of healthy foods in a grocery purchase by dividing a cart or basket using a physical barrier into a healthy foods section and another section. Furthermore, Wansink et al. (2017) demonstrate that consumers buy more fruits and vegetables when using a partitioned shopping cart combined with a healthy/nutrition flyer. Furthermore, Van den Bergh et al (2011), found basket users to have a higher propensity to buy vice products at the cash register compared to shopping cart users. 


\section{Toward a Research Agenda}

\subsection{Main contribution}

We have exposed how limited the literature is on in-store carrying equipment, and that this literature is greatly varied, especially when classified into different research themes. Beside a systematic literature review, our contribution is a conceptual model that covers the most important factors affecting the choice of in-store carrying equipment, as well as the consequences of these choices in terms of in-store behaviors and transactional outcomes. We used this model to integrate the relevant research on in-store carrying equipment as well as to identify important gaps in the literature. More insight into these issues is important to retailers because there is a belief that carrying equipment use has a connection to in-store behavior as well as transactional outcomes, such as sales numbers. For academics, such data can lead to a further understanding of consumer behavior in a store, as well as increased competencies related to technological innovation or health promotion.

Since the conceptual model organizes knowledge gathered from the literature review, it provides a research framework for further studies on in-store carrying equipment. It is clear that there must be an increase in research on this topic. We can hypothesize about results, but we need studies to confirm many of the expectations mentioned throughout the paper. Future research and experimentation should be coming from real-world observation, rather than laboratory observation, and technology now exists to make this possible. By using new technology, such as RFID, video surveillance and retail analytics, researchers and retail managers have a new way to measure and observe in-store customer behaviors and shopping trips like never before. Research can consist of both experimental work and studies using 
observations in combination with software solutions enabling consumer tracking, along with exit interviews. The conceptual model can be used by both academics and retailers as a working model to design experiments and other studies on the effects of different types and designs of carrying equipment in physical retailing. Retailers specifically can test the suitability of new technology, such as different versions of smart shopping carts or baskets, interactions with smart shelves, or automation.

\subsection{Further research suggestions and managerial advice}

As an encouragement for further research on the topic of in-store carrying equipment in retailing and consumer behavior, we complete the current paper by making specific suggestions for further research centered on some of the more significant gaps we have identified. We use the factors in the conceptual model to organize these suggestions.

Consumer factors. There is a need for research on how consumers' shopping goal/mission established prior to the store visit, is related to the choice of carrying equipment. A fundamental question in this respect is also how frequently, to what extent, and at what point in the shopping trip, unplanned buying results in consumers reaching their maximum carrying capacity. Further, the literature is very limited when it comes to attitudes and experiences related to in-store carrying equipment within the general population, other than older shoppers.

Retail factors. We see a need for rigorous experimental work on the availability of carrying equipment in different retail contexts (options/types/designs), the effects of consumer effort when choosing one option instead of other options available, and how benefits attached to the use of a particular option (rebates, reward points etc.) influence its attractiveness (and use) in the retail environment. This is an area where retailers themselves also can do their own 
experiments and see what works. Their preferred choice is consumers selecting a shopping cart due to its capacity and increasing promotional possibilities brought forward by technology. In Table 3 we present a list of suggested interventions that retailers can use to promote or increase the likelihood of their customers selecting a shopping cart or a new innovative solution, such as a smart cart, and thus increasing their potential. We have used the retail factors in our conceptual model (left side, Figure 1) to organize these interventions.

The choice itself. The literature is rather scarce when it comes to research on consumers' choice of carrying equipment (what they actually use), and in particular, data on non-equipment usage relative to the use of baskets and carts in different retail formats. It is reasonable to expect that non-equipment usage in many countries has increased in scope in recent years as a result of consumers replacing their weekly shop with more frequent visits to the store. Data on nonequipment usage could shed more light on this change in consumer habits, and help to uncover how widespread this phenomenon is. 
Table 3. Possible in-store interventions in line with the conceptual model, aimed at increasing the adoption of carrying equipment

Effort \& availability
Clearly outline all new and existing convenience features that
carts have, for example drink holders, carts with children's
seats, smart carts, etc.
For carrying equipment that is located near the entrance, place it
further from the entry doors as to not have it be in the
"transition zone”, being the area where customers transition
from walking into store to where they begin shopping
(Underhill, 2009).

Design multiple return points for carts so that it is easy for customers to leave their cart after shopping. Both at the checkout, and in the parking lot.

Offer bulk products that offer value to the customer, while at the same time, requiring a cart to transport. Use new marketing to bring public attention to change (Cochoy, 2008; Underhill, 2009)

Avoidance of any structural barriers associated with consumers deselecting a shopping cart (e.g. Cart locks).

Have clear directions for using smart cart innovation that can be understood by all (specifically, the older generation who rely on carts).

Design carts so that they are easier to navigate (effort while shopping). If connected with a store app, a pre-made shopping lists that match up with the cart's positioning within the store could provide the shopper an efficient way to shop the store.

Have additional carrying equipment located in other high traffic areas of the store, besides the entrance, so customers can upgrade their choice if needed (Underhill, 2009).

Make it easier for customers to access their cars with shopping carts, in case they are buying in bulk or heavy items that are difficult to carry.

\section{Attractiveness \& incentives}

Attached to the carrying equipment itself, list facts such as the average number of types of foods purchased, to normalize attitudes of expected basket size and contents (Payne et al., 2014).

If cart selection is preferred over basket selection, adapt internally (in-store) and externally (out of store) to promote larger shopping trips rather than small, frequent trips.

Experiment with smaller shopping carts that are more in line with the needs of customers that shop the store more frequently (Nielsen, 2015).

Draw attention to the benefits of using a smart cart (e.g. innovations, Rebates, reward points, shopping effectiveness, etc.) (Kahl et al., 2011).

Enhance the store image of being a value store, where basket sizes are typically higher.

Introduce smart carts with solutions that consumers find attractive (e.g. personalized shopping lists, recipes, food nutritional information, etc.).

Creating a more pleasant shopping experience will increase time spent in store, which increases the chances that a larger carrying equipment will be used (Gil et al., 2009; Underhill, 2009).

Offer items like sanitizing wipes for cart and baskets aimed at customers who have hygiene concerns.

Offer customers with children incentives to spend longer time in the store, such as offering children free fruits or entertainment.

Smartphone holders attached to carrying equipment

Outcomes/consequences/behaviors. There is a need for more empirical data on how shopping trips involving different types of in-store carrying equipment differ in terms of in-store behaviors and transactional outcomes. Because grocery stores are designed primarily for stock-up shoppers, it is reasonable to expect cart users, basket users and non-equipment users to exhibit for instance significantly different shopping efficiency (such as the number of meters walked per item purchased), with the latter shopper segment most likely being the least efficient. Retailers 
need such data to re-evaluate their store designs and format strategies, to make them more efficient for all shoppers. Analyzing carrying equipment and the retail factors (see Table 3) as behavior modification is also something that has not yet been adequately explored in the literature. We therefore suggest that further research on in-store carrying equipment look at shopping carts and baskets as behavioral modification tools that affect how shoppers interact with their surroundings in the store. Finally, our literature review shows that researchers have not paid enough attention to the side uses of shopping carts. There are a few studies on the presence of children in shopping carts, but the focus is mainly on safety issues. Our suggestion is therefore to study shopping carts as playgrounds, where the emphasis is on the family as a decisionmaking unit. For instance, studying the role of children in both the adoption of carrying equipment as well as the effects on the shopping experience and behavior, could reveal interesting insights. 


\section{References}

Angell, R. J., Megicks, P., Memery, J., and Heffernan, T. W. 2014 [48]. Older shopper types from store image factors. Journal of Retailing and Consumer Services, 21(2), 192-202.

Al-Ghamdi, A. K., Abdelmalek, S. M. A., Ashshi, A. M., Faidah, H., Shukri, H. and JimanFatani, A. A. 2011 [37]. "Bacterial contamination of computer keyboards and mice, elevator buttons and shopping carts. African Journal of Microbiology Research, 5(23), 3998-4003.

Aylott, R., and Mitchell, V. W. 1998 [24]. An exploratory study of grocery shopping stressors. International Journal of Retail and Distribution Management, 26(9), 362-373.

Barker, M. R., Bailey, J. S., and Lee, N. 2004 [11]. The impact of verbal prompts on child safety-belt use in shopping carts. Journal of Applied Behavior Analysis, 37(4), 527-530.

Beatty, S. E., and Smith, S. M. 1987. External search effort: An investigation across several product categories, Journal of Consumer Research, 14, 83-95.

Bell, D. R., Corsten, D., and Knox, G. 2011. From Point of Purchase to Path to Purchase: How Preshopping Factors Drive Unplanned Buying. Journal of Marketing, 75(1), 31-45. doi:10.1509/jmkg.75.1.31

Burke, R.R. and Morgan, N.A 2017. Benchmarking retail shoppability. Journal of Shopper Research. Spring, 50-59.

Burns, J. 2016. And The Patent For Robotic Shopping Carts Goes To... Walmart? Retrieved from https://www.forbes.com/sites/janetwburns/2016/09/30/and-the-patent-for-roboticshopping-carts-goes-to-walmart/\#46c9ecf79af0

Campbell, M., Ferguson, J., and Beattie, T. F. 1990 [34]. Are falls from supermarket trolleys preventable? BMJ: British Medical Journal, 301(6765), 1370. 
Clayton, M. C., Boron, J.B., and Mattila, L. 2014 [9]. Child Safety in Grocery Stores: The Impact of Verbal Prompts and Reinforcement on Safety Strap Use in Shopping Carts. Journal of Organizational Behavior Management, 34(1), 52-58.

Cochoy, F. 2008 [1]. Calculation, qualculation, calqulation: shopping cart arithmetic, equipped cognition and the clustered consumer. Marketing Theory, 8(1), 15-44. doi:10.1177/1470593107086483

Cochoy, F. 2009 [12]. Driving a Shopping Cart from STS to Business, and the Other Way Round: On the Introduction of Shopping Carts in American Grocery Stores (19361959). Organization, 16(1), 31-55. doi:10.1177/1350508408098921

Davies, G. and Bell, J. 1991. The grocery shopper — Is he different?, International Journal of Retail \& Distribution Management, 19(1), 25-29.

De Groot, J. I., Abrahamse, W., and Jones, K. 2013 [49]. Persuasive normative messages: The influence of injunctive and personal norms on using free plastic bags. Sustainability, 5(5), 1829-1844.

Dominici, G., Matić, M., Abbate, T., and Fatta, D. D. 2016 [20]. Consumer attitude toward using smart shopping carts: a comparative analysis of Italian and Croatian consumer attitudes. International Journal of Electronic Marketing and Retailing, 7(3), 229-244. doi: 10.1504/IJEMR.2016.078952

Elkington, J. 2013. Enter the triple bottom line. The triple bottom line (pp. 23-88). Routledge. Evanschitzky, H., Iyer, G. R., Pillai, K. G., Kenning, P., and Schütte, R. 2015 [7]. Consumer trial, continuous use, and economic benefits of a retail service innovation: the case of the personal shopping assistant. Journal of Product Innovation Management, 32(3), 459-475. 
Fagerstrøm, A., and Sigurdsson, V. 2016. Experimental analysis of consumer choices. The Routledge companion to consumer behavior analysis, in Foxall, G. R. (ed.). The Routledge companion to consumer behavior analysis, London: Routledge, 25-39.

Ferrari, J.R., and Baldwin, C.H. 1989a [19]. Promoting safety belt use in shopping carts buckle-up your baby. Environment and Behavior, 21(5), 603-619. doi: 10.1177/0013916589215005

Ferrari, J.R., and Baldwin, C.H. 1989b [59]. From cars to carts - Increasing safety belt usage in shopping carts. Behavior Modification, 13(1), 5-64. doi: 10.1177/01454455890131003

Foxall, G. R. 1998. Radical behaviorist interpretation: generating and evaluating an account of consumer behavior. The Behavior Analyst, 21(2), 321-354.

Foxall, G. R. (Ed.) 2015. The Routledge companion to consumer behavior analysis. London: Routledge.

Foxall, G., 2017. Advanced introduction to consumer behavior analysis. Edward Elgar Publishing.

Gerba, C. P., and Maxwell, S. 2012 [39]. Bacterial contamination of shopping carts and approaches to control. Food protection trends, 32(12), 747-749.

Geuens, M., Brengman, M., \& S'Jegers, R. 2003 [41]. Food retailing, now and in the future. A consumer perspective. Journal of Retailing and Consumer Services, 10(4), 241-251.

Gil, J., Tobari, E., Lemlij, M., Rose, A., and Penn, A. R. 2009. The Differentiating Behaviour of Shoppers: Clustering of individual movement traces in a supermarket. In: Koch, D., Marcus, L. and Steen, J. (eds.). Proceedings of the 7th International Space Syntax Symposium. Royal Institute of Technology (KTH): Stockholm, Sweden. 
Grandclément, C. 2009. Wheeling one’s groceries around the store: The invention of the shopping cart, 1936-1953, in Belasco, W. and Horowitz, R. (Eds), Food Chains: Provisioning from Farmyard to Shopping Cart, University of Pennsylvania Press, 414448.

Grewal, D., Roggeveen, A.L. and Nordfält, J. eds., 2014. Shopper Marketing and the Role of Instore Marketing. In Shopper Marketing and the Role of In-Store Marketing (p. iii). Emerald Group Publishing Limited.

Hagberg, J., and Normark, D. 2015 [13]. From basket to shopping bag: Retailers’ role in the transformation of consumer mobility in Sweden, 1941-1970. Journal of Historical Research in Marketing, 7(4), 452-475.

Hanson, N. 2015 [62]. "Mobility-things” and consumption: conceptualizing differently mobile families on the move with recent purchases in urban space. Consumption Markets \& Culture, 18(1), 72-91. doi: 10.1080/10253866.2014.899494

Harrell, W. A. 1994 [28]. The impact of shopping cart restraints and adult supervision on near injuries to children in grocery stores. Accident Analysis \& Prevention, 26(4), 493-500.

Harrell, W. A. 1996 [31]. The effects of shopping cart design and prior behavioral history on children's standing in cart seats. Accident Analysis \& Prevention, 28(3), 385-389.

Harrell, W. A. 2003a [10]. Effect of two warning signs on adult supervision and risky activities by children in grocery shopping carts. Psychological reports, 92(3), 889-898.

Harrell, W. A. 2003b [42]. Safety of children in grocery carts: Adults' personal health and safety habits. Psychological reports, 92(3), 908-914.

Harrell, W. A. 2003c [43]. Dangerous activities by children in grocery carts: is adult supervision important? Psychological reports, 92(3), 957-962. 
Harrell, W. A., and Reid, E. E. 1990 [30]. Safety of children in grocery stores: the impact of cartseat use in shopping carts and parental monitoring. Accident Analysis \& Prevention, 22(6), 531-542.

Hosbond, J. H., and Skov, M. B. 2007 [33]. Micro mobility marketing: Two cases on locationbased supermarket shopping trolleys. Journal of Targeting, Measurement and Analysis for Marketing, 16(1), 68-77.

Hui, S. K., Bradlow, E. T., and Fader, P. S. 2009a [57]. Testing Behavioral Hypotheses Using an Integrated Model of Grocery Store Shopping Path and Purchase Behavior. Journal of Consumer Research, 36(3), 478-493. doi:10.1086/599046

Hui, S.K., Fader, P.S. \& Bradlow, E.T. 2009b [55]. The traveling salesman goes shopping: the systematic deviations of grocery paths from TSPOptimality. Marketing Science, 28(3), $566-572$.

Hui, S. K., Inman, J. J., Huang, Y. and Suher, J. 2013. The Effect of In-Store Travel Distance on Unplanned Spending: Applications to Mobile Promotion Strategies. Journal of Marketing, 77(2), 1-16. doi:10.1509/jm.11.0436

Inman, J.J., Winer, R.S., \& Ferraro, R. 2009. The interplay among category characteristics, customer characteristics, and customer activities on in-store decision making. Journal of Marketing, 73, 19-29.

Johnson, E. J., Shu, S. B., Dellaert, B. G., C., Fox, C., Goldstein, D. G., . . W Weber, E. U. 2012. Beyond nudges: Tools of a choice architecture. Marketing Letters, 23(2), 487-504. doi: 10.1007/s11002-012-9186-1 
Kahl, G., Spassova, L., Schöning, J., Gehring, S., Krüger, A. 2011. IRL SmartCart - A Useradaptive Context-aware Interface for Shopping Assistance. Proceedings of the $16^{\text {th }}$ international conference on Intelligent user interfaces. Palo Alto, CA.

Krippendorff, K. 1989. Content analysis, in Barnouw, E., Gerbner, B., Schramm, W., Worth, T. L. and Gross, L. (Eds.), International encyclopedia of communication, Vol. 1, New York, NY: Oxford University Press, 403-407.

Kohijoki, A. M. 2011 [47]. The effect of aging on consumer disadvantage in grocery retail services among the Finnish elderly. Journal of Retailing and Consumer Services, 18(4), $370-377$.

Kourouthanassis, P. 2003 [14]. Can technology make shopping fun? International Commerce Review: ECR Journal, 3(2), 37-44.

Kulyukin, V., Gharpure, C., and Coster, D. 2008 [60]. Robot-assisted shopping for the visually impaired: proof-of-concept design and feasibility evaluation. Assistive Technology, 20(2), 86-98. doi: 10.1080/10400435.2008.10131935

Kwong, E. W. Y., Lail, C. K. Y, Spicciolato, E. and Wong, M. C. M. 2010 [35]. Views of Adults on Shopping Trolleys: Implications for the Development of a Shopping Trolley. The Ergonomics Open Journal, 3, 32-37.

Larsen, N. M., Sigurdsson, V. and Breivik, J. 2017 [53]. The use of observational technology to study in-store behavior: consumer choice, video surveillance, and retail analytics. The Behavior Analyst, 40(2), 343-371. doi: 10.1007/s40614-017-0121-x

Larson, J. S., Bradlow, E. T., and Fader, P. S. 2005 [21]. An exploratory look at supermarket shopping paths. International Journal of Research in Marketing, 22(4), 395-414. doi: 10.1016/j.ijresmar.2005.09.005 
Leighton, C., and Seaman, C. E. A. 1997 [51]. The elderly food consumer: disadvantaged? Journal of Consumer Studies \& Home Economics, 21(4), 363-370. doi:10.1111/j.14706431.1997.tb00294.x

Marshall, D. 2014 [54]. Co-operation in the supermarket aisle: young children's accounts of family food shopping. International Journal of Retail \& Distribution Management, 42(11/12), 990-1003.

Martin, K. J., Chounthirath, T., Xiang, H., and Smith, G. A. 2014 [17]. Pediatric shopping-cartrelated injuries treated in US emergency departments, 1990-2011. Clinical pediatrics, 53(3), 277-285.

Mason, J. B., and Bearden, W. O. 1979 [22]. Satisfaction/dissatisfaction with food shopping among elderly consumers. The Journal of Consumer Affairs, 359-369.

Meneely, L., Burns, A., and Strugnell, C. 2008 [46]. Food retailers' perceptions of older consumers in Northern Ireland. International Journal of Consumer Studies, 32(4), 341348. doi:10.1111/j.1470-6431.2007.00644.x

Meneely, L., Strugnell, C., and Burns, A. 2009 [45]. Elderly consumers and their food store experiences. Journal of Retailing and Consumer Services, 16(6), 458-465. doi:10.1016/j.jretconser.2009.06.006

Mitchell, V., and Harris, G. 2005 [61]. The importance of consumers’ perceived risk in retail strategy. European Journal of Marketing, 39(7/8), 821-837

Mizumachi, E., Kato, F., Hisatsune, J., Tsuruda, K., Uehara, Y., Seo, H., and Sugai, M. 2011 [38]. Clonal distribution of enterotoxigenic Staphylococcus aureus on handles of handheld shopping baskets in supermarkets. Journal of applied microbiology, 110(2), $562-567$. 
Moutinho, L. and Hutcheson, G.D. 2007 [50]. Store choice and patronage: A predictive modelling approach. Int. J. Business Innovation and Research, 1(3), 233-252.

Nielsen 2015. The future of grocery: e-commerce, digital technology and changing shopping preferences around the world. Retrieved June 10, 2017 from http://www.nielsen.com/us/en/insights/reports/2015/the-future-of-grocery.html

Pandey, J., and Darla, A. M. 2012 [52]. A Study on the influence of store level services on store loyalty of shoppers in organized retail stores. International Journal of Management Research and Reviews, 2(4), 600-622.

Park, C.W., Iyer, E.S., \& Smith, D.C. 1989. The effects of situational factors on in-store grocery shopping behavior: The role of store environment and time available for shopping. Journal of Consumer Research, 15(4), 422-433. doi: 10.1086/209182

Parry, M. L., Morrison, L. G. L., Chalmers, D. J., and Wright, C. S. 2002 [32]. Shopping trolleyrelated injuries to children in New Zealand, 1988-97. Journal of Pediatrics and Child Health, 38(1), 51-54.

Patrick, M. E., Mahon, B. E., Zansky, S. M., Hurd, S., and Scallan, E. 2010 [16]. Riding in shopping carts and exposure to raw meat and poultry products: prevalence of, and factors associated with, this risk factor for salmonella and campylobacter infection in children younger than 3 years. Journal of Food Protection, 73(6), 1097-1100.

Payne, C. R., Niculescu, M., Just, D. R., and Kelly, M. P. 2014. Shopper marketing nutrition interventions. Physiology \& Behavior, 136, 111-120.

Pettigrew, S., Mizerski, K., \& Donovan, R. 2005 [23]. The three “big issues” for older supermarket shoppers. Journal of Consumer Marketing, 22(6), 306-312. doi:10.1108/07363760510623894

Reimers, V. 2014 [26]. A consumer definition of store convenience (finally). International Journal of Retail \& Distribution Management, 42(4), 315-333. 
Sales, J., Martí, J. V., Marín, R., Cervera, E., and Sanz, P. J. 2016 [58]. CompaRob: the shopping cart assistance robot. International Journal of Distributed Sensor Networks, 12(2). doi: $10.1155 / 2016 / 4781280$

Schumann, D. W., Grayson, J., Ault, J., and Hargrove, K. 1991 [3]. The effectiveness of shopping cart signage: Perceptual measures tell a different story. Journal of Advertising Research, 31(1), 17-22.

Seiler, S., and Pinna, F. 2017 [56]. Estimating search benefits from path-tracking data: measurement and determinants. Marketing Science, 36(4), 471-643.

Siebers, L.Q., Tao Zhang, T., and Li, F. 2013 [63]. Retail positioning through customer satisfaction: an alternative explanation to the resource-based view. Journal of Strategic Marketing, 21(7), 559-587. doi: 10.1080/0965254X.2013.817478

Sigurdsson, V., Larsen, N. M., and Fagerstrøm, A. 2016. Behavior analysis of in-store consumer behavior. in Foxall, G. R. (ed.). The Routledge companion to consumer behavior analysis, London: Routledge, 40-50.Skinner, B.F., 1981. Selection by consequences. Science, 213(4507), 501-504.

Smith, G. A., Dietrich, A. M., Garcia, C. T., and Shields, B. J. 1995 [29]. Epidemiology of shopping cart-related injuries to children: an analysis of national data for 1990 to 1992. Archives of pediatrics \& adolescent medicine, 149(11), 1207-1210.

Smith, G. A., Dietrich, A. M., Garcia, C. T., and Shields, B. J. 1996 [15]. Injuries to children related to shopping carts. Pediatrics, 97(2), 161-165.

Sorensen, H. 2016. Inside the mind of the shopper: The science of retailing. Second Edition. Old Tappan, New Jersey: Pearson Education. 
Thaler, R., and Sunstein, C. 2008. Nudge: The gentle power of choice architecture. New Haven, Conn.: Yale.

TNSglobal.com. 2017. Happy shoppers spend more. Kantar TNS. http://www.tnsglobal.com/intelligence-applied/happy-shoppers-spend-more (Accessed Dec 8, 2017).

Trinkaus, J.W. 2004a [8]. Clearing the supermarket shopping cart: An informal look. Psychological Reports. 94, 1442-1443. doi: 10.2466/pr0.94.3c.1442-1443.

Trinkaus, J. W. 2004b [40]. Disposing of the Empty Shopping Market Cart—An Informal Look. Psychological reports, 95(1), 107-108.

Underhill, P. 2009. Why we buy: The science of shopping. New York, NY: Simon and Schuster. Van Den Bergh, B., Heuvinck, N., Schellekens, G. A., and Vermeir, I. 2016. Altering speed of locomotion. Journal of Consumer Research, 43(3), 407-428.

Van den Bergh, B., Schmitt, J. and Warlop 2011 [4]. Embodied Myopia. Journal of Marketing Research, 48(6), 1033-1044.

Van Ittersum, K., Wansink, B., Pennings, J. M., and Sheehan, D. 2013 [2]. Smart shopping carts: how real-time feedback influences spending. Journal of Marketing, 77(6), 21-36.

Vilke, G. M., Stepanski, B. M., Ray, L. U., Lutz, M. W., Murrin, P. A., and Chan, T. C. 2004 [18]. 9-1-1 responses for shopping cart and stroller injuries. Pediatric emergency care, 20(10), 660-663.

Wagner, U., Ebster, C., Eske, U., and Weitzl, W. 2014 [44]. The Influence of Shopping Carts on Customer Behavior in Grocery Stores. Marketing ZFP, 36(3), 165-175.

Wang, Y-C., and Chang, C-C. 2016 [36]. 3S-cart: A Lightweight, Interactive Sensor-Based Cart for Smart Shopping in Supermarkets. IEEE Sensors Journal, 16(17), 6774 - 6781 
Wansink, B. 2017. Healthy profits: An interdisciplinary retail framework that increases the sales of healthy foods. Journal of Retailing, 93(1), 65-78. doi:http://dx.doi.org/10.1016/j.jretai.2016.12.007

Wansink, B., Soman, D., and Herbst, K. C. 2017 [5]. Larger partitions lead to larger sales: Divided grocery carts alter purchase norms and increase sales. Journal of Business Research, 75, 202-209.

Wansink, B., Payne, C. R., Herbst, K. C., and Soman, D. 2013 [27]. Part carts: Assortment allocation cues that increase fruit and vegetable purchases. Journal of Nutrition Education and Behavior, 45(4), S42.

Wright, J. W., Griffin, R., MacLennan, P. A., Rue, L. W., and McGwin, G. 2008 [6]. The incidence of shopping cart-related injuries in the United States, 2002-2006. Accident Analysis \& Prevention, 40(3), 1253-1256.

Yin, Y., Pei, E., and Ranchhod, A. 2013 [25]. The shopping experience of older supermarket consumers. Journal of Enterprise Information Management, 26(4), 444-471. doi:10.1108/JEIM-05-2013-0025 